\title{
Heavy metal concentration in some freshwater fishes during autumn and winter in Mymensingh district of Bangladesh
}

\author{
MD. ABUL MANSUR* ${ }^{*}$ MD. NURUL HAIDER, MD. MUBARACK HOSSAIN, \\ MD. MANIK MIA ${ }^{1}$ AND MITHUN KARMAKAR ${ }^{1}$ \\ Department of Fisheries Technology, Bangladesh Agricultural University, Mymensingh 2202, Bangladesh \\ ${ }^{1}$ Quality Control Laboratory, Department of Fisheries, Savar, Dhaka \\ *Corresponding Author: mansurft63@gmail.com
}

\begin{abstract}
Study was conducted to determine the heavy metal concentration in 5 freshwater fishes Heteropneustes fossilis, Clarias batrachus, Anabus testudineus, Oreochromis niloticus, and Mystus gulio during autumn and winter. Most widely eaten five freshwater fish species were selected for this purpose. These fish species were Among the heavy metals estimated in this study $(\mathrm{Cd}, \mathrm{Cr}, \mathrm{Pb}, \mathrm{Cu}, \mathrm{Zn})$ the $\mathrm{Cd}, \mathrm{Cu}$, $\mathrm{Zn}$ were within the acceptable level but $\mathrm{Cr}$ and $\mathrm{Pb}$ concentration was above the maximum allowable limit. $\mathrm{The} \mathrm{Cd}, \mathrm{Cr}, \mathrm{Pb}$ concentration in the fish muscle was higher in winter as compared to that of autumn but the $\mathrm{Cu}$ and $\mathrm{Zn}$ concentration was higher in autumn when compared to that of winter. Result of the present research indicates that the heavy metal concentration in fish muscle significantly varies with season. Some heavy metal were within the acceptable level in autumn season but above the maximum allowable limit in winter season. In $H$. fossilis, $C$. batrachus, and $O$. niloticus, heavy metal concentration was within the acceptable level but in $A$. testudineus and $M$. gulio heavy metal concentration was above the maximum allowable limit. So heavy metal concentration varied with season as well as with species of fish.
\end{abstract}

Keywords: Heavy metals, Freshwater fish, Seasonal differences

\section{Introduction}

Heavy metal pollution in food particularly aquatic food is a major concern of many countries of the world. Due to some reasons the aquatic environment is getting polluted day by day. Major source of heavy metal pollution in fish and shell fish are: waste dump including hospital waste, industrial waste discharge, lagoon, and low grade ingredients of fish feed. Fish and other aquatic animals are capable of absorbing and concentrating these pollutants in their body by a process known as bioaccumulation. Sometimes it cause severe injury to health or death by eating such contaminated fish for a long time. It is therefore growing concern throughout the world with the impact of pollutants on the quality and safety of fish and fishery products. Recently the pollution by heavy metal is the great concern in many countries including Bangladesh. Many countries are now taking voluntary or mandatory action to reduce pollution of the aquatic environment with heavy metal. To a large extent these are matters of a relatively long term nature to be tackled at national and international level (Connell 1980). European Union has adopted provisions and regulations (EEC 1991)laying down the health conditions for the production and the placing on the market of fishery products in which monitoring heavy metal level and calculated dietary intake as acceptable daily or weekly intake for human. Most common heavy metals in fish from aquatic environment are: Mercury $(\mathrm{Hg})$, Lead $(\mathrm{Pb})$, Cadmium $(\mathrm{Cd})$, Chromium $(\mathrm{Cr})$, Copper $(\mathrm{Cu})$, Zinc $(\mathrm{Zn})$. Heavy metal poisoning has been described by many scientists and Organizations (Holden 1973, Johnson 1976, Joint FAO/WHO 1972, MAFF 1972, 1973).Clucas and Ward (1996) mentioned that heavy metals enter the aquatic environment, mainly as a result of industrial pollution, and find their way into food chain by a number of routes. In Bangladesh,

https://doi.org/10.52168/bjf.2021.33.10 
HEAVY METAL CONCENTRATION IN FRESHWATER FISHES DURING AUTUMN AND WINTER

freshwater fishery contributes nearly $70 \%-75 \%$ of total fish production. Freshwater fishes and prawn are eaten much in Bangladesh and a sizeable quantity is exported to the International Market. At present the Fish Farms, Aquaculture Farms producing a huge quantity of fish in Mymensingh district. About 25 years ago the heavy metal concentration in most of the fishes of Bangladesh was undetectable. But in recent studies it has been found that fish and fishery products of Bangladesh water is polluted by different heavy metal, some are above maximum allowable limit (Mansur et. al. 2013, 2014, 2016, 2017a, 2017b, Reza et. al., 2020, Hossain et. al. 2017, Jamil et. al. 2017). Considering the necessity of heavy metal check in fish and fishery products of Bangladesh the present research was undertaken to reveal the level of heavy metal $(\mathrm{Cd}, \mathrm{Cr}, \mathrm{Pb}, \mathrm{Cu}$ and $\mathrm{Zn})$ in the freshwater fish of Mymensingh. Also to know whether this level changes in different seasons of the year.

\section{Materials and Methods}

Source of fish: Heteropneustes fossilis, Clarias batrachus, Anabas testudineus, Oreochromis niloticus, and Mystus gulio were purchased from K.R. Market, Bangladesh Agricultural University, Mymensingh, Bangladesh. The fishes were in live condition except Mystus gulio which was in chilled condition during purchase. Fish of each species weighed about $1-2 \mathrm{~kg}$ were taken in separate polyethylene bag which were rapidly transported to the laboratory. The raw materials of this research were purchased from the same supplier in each season i.e. autumn, winter, for a better comparison of results. For heavy metal analysis six fillets were taken from six different fishes.

Freshness test: Freshness of the raw fishes was determined by organoleptic examination according to the methods of Howgate et al. (1992). Seven characters were judged and defect points were given on the basis of defect character (Table I). Finally grading of fishes was done by summing the defect points and then by dividing the sum of defect points by 7 (Table II). It should be noted that defect point 5 for any one of the seven characters indicate that the fish is in the grade $\mathrm{C}$ and should be rejected.

Heavy metal analysis: Determination of Heavy Metal content of Fish muscle is carried out according to the methods of Clesceri et al. (1989) and Eboh et al. (2006). Sample preparation and digestion for heavy metal determination was carried out according to the method of Mansur et. al. $(2013,2014)$.

Analysis by Atomic Absorption Spectrophotometer: The digested and diluted sample was subjected to analysis by Atomic Absorption Spectrophotometer. The wave length for such measurement was for As, $\mathrm{Cr}$ and $\mathrm{Cd}$ was $193.7 \mathrm{~nm}, 127 \mathrm{~nm}$ and $217 \mathrm{~nm}$ respectively. The absorbance and corresponding concentration of heavy metal was determined from a standard graph which was previously prepared by standard compound of heavy metal. 
MD. ABUL MANSUR et al.

Table I. Defect characters with corresponding defect points of fishes for SDP estimation

\begin{tabular}{|c|c|c|c|}
\hline Characters & Defect & Defect point & Grade \\
\hline Odour of neck & $\begin{array}{l}\text { 1. Natural odour/Neutral odour } \\
\text { 2. Faint or medium or strong sour odour or putrid. }\end{array}$ & $\begin{array}{l}2 \\
5\end{array}$ & Reject \\
\hline Odour of gills & $\begin{array}{l}\text { 1. Neutral odour } \\
\text { 2.Faint sour odour } \\
\text { 3. Slight to moderate sour odour } \\
\text { 4. Moderate to strong sour odour }\end{array}$ & $\begin{array}{l}1 \\
2 \\
3 \\
5\end{array}$ & Reject \\
\hline Colour of gills & $\begin{array}{l}\text { 1. Slightly pink red. } \\
\text { 2. Pinkish red, brownish red, some mucus may be } \\
\text { present } \\
\text { 3. Brown or gray and may be covered with Mucus }\end{array}$ & $\begin{array}{l}1 \\
2 \\
3\end{array}$ & \\
\hline $\begin{array}{l}\text { General } \\
\text { appearance }\end{array}$ & $\begin{array}{l}\text { 1. Very little if any bleaching } \\
\text { 2. Some loss of metallic cluster, some bleaching } \\
\text { may be apparent. } \\
\text { 3. Colour faded or bleaches }\end{array}$ & $\begin{array}{l}1 \\
2 \\
3\end{array}$ & \\
\hline Eyes & $\begin{array}{l}\text { 1 May be slightly sunken or somewhatdull } \\
\text { 2.Dull, slightly sunken and/or slightly cloudy } \\
\text { 3. Dull, sunken, cloudy }\end{array}$ & $\begin{array}{l}1 \\
2 \\
3\end{array}$ & \\
\hline Slime & $\begin{array}{l}\text { 1. Usually clear, transparent, uniformly spread out } \\
\text { occasionally may be slightly opaque or milky } \\
\text { 2. Becoming turbid opaque and milky, with } \\
\text { marked increase in amount of slime present on skin } \\
\text { 3. Thick, sticky, yellowish or grayish Colour }\end{array}$ & $\begin{array}{l}2 \\
5\end{array}$ & Reject \\
\hline $\begin{array}{l}\text { Consistency of } \\
\text { flesh }\end{array}$ & $\begin{array}{l}\text { 1. Firm and elastic to touch. Occasionally may be } \\
\text { slightly soft } \\
\text { 2. Moderately soft and some loss of elasticity. } \\
\text { 3. Generally soft and flabby. }\end{array}$ & $\begin{array}{l}1 \\
2 \\
5\end{array}$ & Reject \\
\hline
\end{tabular}

Formula:

$\mathrm{SDP}=\underset{\mathrm{n}}{\sum \mathrm{DP}}$

where, SDP is Score of Defect Point, DP is Defect points, $\mathrm{n}$ is number of characters

Table II. Grading of Fish

\begin{tabular}{c|l|c|c}
\hline Grade & SDP & \multicolumn{2}{|c}{ Comment } \\
\hline A & $<2$ & Excellent & Acceptable \\
\hline B & 2 to $<5$ & Good & Acceptable \\
\hline C & 5 & Bad & Reject \\
\hline
\end{tabular}

Calculation: The actual concentration of heavy metal was calculated by the following formula:

Heavy Metal Conc. $(\mathrm{ppm})=$ ppm conc. Observed $\mathrm{x}$ Final volume of sample in $\mathrm{ml}$

Weight of Sample in $\mathrm{g}$ 


\section{Results and Discussion}

Freshness: In autumn and in winter the raw materials of this research were in excellent condition i.e. Grade A (Table III). It indicates that the fishes were apparently of very good quality before use in this research. Freshness of raw fish is important while selecting for research. It is universally accepted that the freshness of raw material should be determined before use. Freshness test by organoleptic method of fish is in practice in European Union before issuing permission for placing in market for selling. It is advised to conduct freshness test by organoleptic method before purchase for use in Fish Processing Industry, for permission to sell in the port markets, departmental store etc.

Table III. Freshness of the fishes

\begin{tabular}{c|l|c|c|c}
\hline \multirow{2}{*}{$\begin{array}{c}\text { Sl. } \\
\text { No. }\end{array}$} & \multirow{2}{*}{ Scientific name } & \multicolumn{3}{|c}{ SDP } \\
\cline { 3 - 5 } & & Autumn & Winter & Grade \\
\hline 1 & Heteropneustes fossilis & 1.87 & 1.56 & $\mathrm{~A}$ \\
\hline 2 & Clarias batrachus & 1.89 & 1.66 & $\mathrm{~A}$ \\
\hline 3 & Anabus testudineus & 1.67 & 1.47 & $\mathrm{~A}$ \\
\hline 4 & Oreochromis niloticus & 1.79 & 1.56 & $\mathrm{~A}$ \\
\hline 5 & Mystus gulio & 1.98 & 1.68 & $\mathrm{~A}$ \\
\hline
\end{tabular}

Heavy metal contents: Cadmium (Cd) concentration was within the maximum acceptable level $(1.0 \mathrm{ppm})$ in both autumn and winter season. Cd causes chronic problem in stomach, cause renal problem, and cause overall health risk. However, the present study shows that the fishes were safe with regard to cadmium concentration in autumn season and winter season.

The $\mathrm{Cr}$ concentration in the fishes was found to be above the maximum acceptable level $(0.05 \mathrm{ppm})$ (Table IV). Chromium (Cr) cause renal disease i.e. problem in kidney of the consumers, it also cause chronic problem in stomach and cause overall health risk if eaten above maximum allowable limit for a long period of time. In $A$. testudineus $\mathrm{Cr}$ concentration was $14.49 \mathrm{ppm}$ in winter season, in $M$. gulio $\mathrm{Cr}$ concentration was $10.80 \mathrm{ppm}$ in autumn season, in C. batrachus $\mathrm{Cr}$ concentration was $9.54 \mathrm{ppm}$ in winter. In $H$. fossilis and $O$. niloticus $\mathrm{Cr}$ concentration was between 3.944 to $6.768 \mathrm{ppm}$ in autumn and winter season. None of the samples possessed $\mathrm{Cr}$ concentration in acceptable level $(0.05 \mathrm{ppm})$ so the $\mathrm{Cr}$ concentration in these fishes was not safe. The $\mathrm{Pb}$ concentration in the muscle of the fishes was above the maximum acceptable level (2.0 ppm) (Table IV). Only one sample i.e. H. fossilis in autumn season possessed $1.64 \mathrm{ppm} \mathrm{Pb}$. It is known that $\mathrm{Pb}$ is a dangerous heavy metal. It cause chronic problem in stomach, renal problem, it also cause overall health risk and in children it cause retarded growth if consumed with food for a long time above maximum allowable limit. It should be of our concern that fish contains $\mathrm{Pb}$ above maximum allowable limit. In $A$. testudineus $\mathrm{Pb}$ concentration was $15.75 \mathrm{ppm}$ in autumn season. In almost all samples, $\mathrm{Pb}$ concentration was above maximum allowable limit in both autumn and in winter. 
MD. ABUL MANSUR et al.

Table IV. Heavy metals concentration (ppm) in freshwater fishes in autumn and winter

\begin{tabular}{l|c|c|c|c|c|c|c}
\hline $\begin{array}{l}\text { Heavy } \\
\text { metal }\end{array}$ & $\begin{array}{c}\text { MAL } \\
\mathrm{ppm}\end{array}$ & Season & H. fossilis & C. batrachus & A. testudineus & O. niloticus & M. gulio \\
\hline $\mathrm{Cd}$ & 1.0 & Autumn & 0.15 & 0.15 & 0.22 & 0.13 & 0.33 \\
\cline { 3 - 8 } & & Winter & 0.44 & 0.63 & 0.63 & 0.44 & 0.44 \\
\hline $\mathrm{Cr}$ & \multirow{2}{*}{0.05} & Autumn & 3.94 & 5.76 & 5.41 & 6.76 & 10.80 \\
\cline { 3 - 8 } & & Winter & 6.54 & 9.54 & 14.49 & 6.50 & 3.81 \\
\hline $\mathrm{Pb}$ & 2.0 & Autumn & 1.64 & 2.55 & 15.75 & 2.52 & 5.91 \\
\cline { 3 - 8 } & & Winter & 5.02 & 5.96 & 6.11 & 6.20 & 4.23 \\
\hline $\mathrm{Cu}$ & \multirow{2}{*}{10.0} & Autumn & 2.37 & 2.72 & 6.43 & 6.22 & 4.17 \\
\cline { 3 - 8 } & & Winter & 1.19 & 1.74 & 1.45 & 1.83 & 0.99 \\
\hline $\mathrm{Zn}$ & \multirow{2}{*}{100.0} & Autumn & 60.11 & 43.55 & 32.72 & 57.00 & 111.60 \\
\cline { 3 - 8 } & & Winter & 29.46 & 40.56 & 27.60 & 29.47 & 33.74 \\
\hline
\end{tabular}

Copper $(\mathrm{Cu})$ concentration was within the maximum acceptable level (10 ppm) (Table IV). $\mathrm{Cu}$ concentration in these fishes was higher in autumn season than that of winter season. $\mathrm{Cu}$ cause unpleasant odour and unpleasant green colour in fish and shellfish. It has toxicological risk, also cause renal problem if eaten above certain level $(10 \mathrm{ppm})$ for a long time. The $\mathrm{Cu}$ concentration of these fishes was within acceptable limit in autumn and winter season. The fishes did not possess any unpleasant colour or odour as the $\mathrm{Cu}$ concentration was within acceptable level. Zinc (Zn) concentration in almost all species of fish of this research was within maximum acceptable level $(100 \mathrm{ppm})$ except $M$. gulio which contained $111.60 \mathrm{ppm}$ in autumn (Table IV). Zn, like $\mathrm{Cu}$, has some adverse effect e.g. cause unpleasant odour and unpleasant green colour in fish and shellfish. It has toxicological risk, also cause renal problem if consumed above certain level $(100 \mathrm{ppm})$ for a long time. $\mathrm{Zn}$ concentration in the muscle of these fishes was within acceptable limit in autumn and winter season except $M$. gulio in autumn. But in general, the $\mathrm{Zn}$ concentration in the muscle of these fishes was higher in autumn season than that of winter season. The fishes did not possess any unpleasant colour or odour as the $\mathrm{Cu}$ concentration was within acceptable level.

Heavy metal concentrations in fish muscle of this research are acceptable when compared with our previous research (Mansur et al. 2018, Kamruzzaman et al. 2018; Mansur et al. 2019). Among the heavy metals analyzed in the present study $(\mathrm{Cd}, \mathrm{Cr}, \mathrm{Pb}, \mathrm{Cu}, \mathrm{Zn})$, the concentrations of $\mathrm{Cd}, \mathrm{Cu}, \mathrm{Zn}$ were within the acceptable level but the concentrations of $\mathrm{Cr}$ and $\mathrm{Pb}$ were above the maximum acceptable level. $\mathrm{Cd}, \mathrm{Cr}, \mathrm{Pb}$ concentration in the fish muscle was higher in winter season but the $\mathrm{Cu}$ and $\mathrm{Zn}$ concentration was higher in autumn season. It indicates that the metals $(\mathrm{Cd}, \mathrm{Cr}, \mathrm{Pb})$ were in higher concentration in the fish muscle in winter season. But the elements $(\mathrm{Cu}, \mathrm{Zn})$ were in higher concentration in fish muscle in autumn season. Result of present research express that the heavy metal (metal and element) concentration in fish muscle significantly varies with season. Some heavy metal were within the acceptable level in autumn season but above the maximum allowable limit in winter season. Exception was observed in $A$. testudineus and M. gulio. In some fishes heavy metal concentration was within the acceptable level but in other fishes e.g. A. testudineus and M. gulio heavy metal concentration was above the maximum allowable limit. So heavy metal concentration varied with season as well as with species of fish. 


\section{HEAVY METAL CONCENTRATION IN FRESHWATER FISHES DURING AUTUMN AND WINTER}

It is known from the experience that heavy metal concentration in fish muscle of Bangladesh was very low i.e. undetectable. But now-a-days the heavy metal concentration is comparatively higher. Even in some instances above the maximum allowable limit. The reason may be high level of water pollution in rivers, coast and in Bay. Source of such pollution may be industrial effluent, waste dump, sewerage disposal, hospital waste, low grade feed ingredients in fish farming etc. Reason behind the variation in heavy metal concentration in different season is that the source of the stated pollution is comparatively higher in a particular season. Variation in heavy metal concentration among species may be due to their feed habit, habitat etc. Heavy metal accumulation in fish muscle takes place as a result of bioaccumulation of such heavy metal in fish muscle. Usually heavy metal is present in water from different sources. When fish takes water and feed from water then heavy metal enters into fish body and accumulate in fish muscle. Repeatedly eating such polluted fish can cause injury to health of the consumers through progressive and irreversible accumulation in the body.

In Bangladesh control of water pollution is necessary to control the level of heavy metal in fish and other aquatic food. An extensive research is necessary to find out the level of heavy metal in fish and other aquatic food. Effect of season, species and other related factors can also be taken into consideration. On the basis of the result of this research it can be concluded that: Heavy metal (metal and element) concentration in fish muscle significantly varies with season; some heavy metal were within the acceptable level in autumn season but above the maximum allowable limit in winter season; and heavy metal concentration in fish muscle significantly varies with species too.

Acknowledgements: This research was conducted by the financial support of Bangladesh Agricultural University, Mymensingh, as part of research project No. 2015/13/BAU and 2017/284/BAU. Heavy metal analysis was conducted in the laboratory of the Bangladesh Institute of Nuclear Agriculture.

\section{Literature Cited}

Clesceri, L.S., A.E. Greenberg and R.R. Trussed, 1989. Standard method for the examinationof water and waste water. $17^{\text {th }}$ ed. American Public Health Association, Washington, DC.

Clucas, I.J. and A.R. Ward, 1996. Toxins and Contaminants of Fish and Shellfish. In: Post Harvest Fisheries Development: A Guide to Handling, Preservation, Processing and Quality. Chatham Maritime, Kent ME4 4 TB, UK.

Connell, J.J., 1980. Intrinsic Quality. In: "Control of Fish Quality (2 ${ }^{\text {nd }}$ ed.). Fishing News Books Ltd. Farnham, Surrey, England. pp. 4-30.

Eboh, L., H.D. Mepa and M.B. Ekpo, 2006. Heavy metal concentration and processing effects on the composition, storage stability and fatty acid profile of 5 common commercially available fish species in Oron Local Government, Nigeria. Food Chem, 97: 490-497.

EEC, 1991. Council Directive, 91/493/EEC: laying down the health conditions for the production and the placing on the market of fishery products. Offic. J. Europ. Comm., L268: 15-34.

FAO, 1988. Fishery Statistics. Food and Agricultural Organisation, Vol. 66, Rome, Italy.

Holden, A. V. 1973. Mercury in fish and shellfish. A Review. J. Food. Tech, 8: 1.

Hossain, M.N., M.G.M. Jamil, M.M. Mia, M.N. Uddin and M.A. Mansur, 2017. Studies on the proximate composition, quality and heavy metal concentration of two sun-dried marine fish (sun-dried silver pomfret and sun-dried perch of Cox's Bazar District of Bangladesh. J. Environ. Sci. Nat. Resour., 10(1): 25-32. 
Howgate, P.A., P. Johnson and K.J. Whittle, 1992. Multilingual guide to EC freshness grades for fishery products. Torry Research Station. Aberdeen. Food Safety Directorate, Ministry of Agriculture, Fisheries and Food, UK. 9p.

Jamil, M.G.M., M.N. Hossain, M.M. Mia, M.A. Mansur and S. Uga, 2017.Studies on the proximate composition, quality and heavy metal concentration of sun-dried Bombay Duck and sun-dried ribbon fish of Cox's Bazar District of Bangladesh. J. Environ. Sci. Nat. Resour., 10 (1): 55-60.

Joint FAO/WHO Expert Committee on Food Additives, 1972. 16 ${ }^{\text {th }}$ Report: Evaluation of certain food additives and contaminants; mercury, lead and cadmium. FAO Nutrition. Meeting Report Ser. No. 51, WHO Tech Report Ser. No. 505; Geneva.

Kamruzzaman, M.A., A. Mahamud, A. Alim, M.S. Hossen, M.A. Islam and M.A. Mansur, 2018. Study on heavy metal content of Oreochromis niloticus, Heteropneustes fossilis and Pangasius sutchi from pond \& openwater. Res. Agric. Livest. Fish., 5(1): 117-126.

MAFF, 1972 and 1973. Working Party on the monitoring of foodstuffs for heavy metals, Reports, $1-4$, Ministry of Agriculture, Fisheries and Food, London, UK.

Mansur, M.A., M.N. Uddin, M.G. M.Jamil, M.M. Mia and M. Karmakar, 2017b. Quality and safety aspect of some traditionally processed freshwater fish and fishery products of Mymensingh district in Bangladesh. Int. J. Curr. Res., 9(11): 61867-61872.

Mansur, M.A., M.N. Uddin, S. Akbar, M.N. Haider, M.M. Mia, U.K. Salma and D. Kimura, 2019. Comparative study on the quality and safety aspect of Climbing perch (Anabas testudineus) and Nile tilapia (Oreochromis niloticus) from pond and openwater of Mymensingh, Bangladesh. Bangladesh $J$. Fish., 31(1): 119-124.

Mansur, M.A., M.S. Rahman, M.N.A. Khan, M.S. Reza, L. Sadia and R. Wahab, 2014. Studies on the quality attributes and safety aspect of semi-fermented fish product. Indian J. Geo-Mar. Sci., 43(6): 949-954.

Mansur, M.A., S.C. Chakraborty, A.K.M. Shafiul Azam, A.K.M.F. Rahman, S. Rahman, 2016. Evaluation of quality and safety aspect of chilled prawn (Macrobrachium rosenbergii) during storage at $-20^{\circ}$ C. Indian J. Geo Mar. Sci., 45 (9): 1188-1194.

Mansur, M.A., S.C. Chakraborty, M.M. Mia, M. Karmakar, S. Rahman, M. Kamruzzaman, and S. Uga, 2018. Comparative study on nutritional composition, freshness and heavy metal concentration of three important freshwater fish (Oreochromis niloticus, Heteropneustes fossilis and Pangasius sutchi) collected from pond and river water of Mymensingh district of Bangladesh. Res. Soc. Diet. Habits, 38(3): 39-47.

Mansur, M.A., S.C. Chakraborty, S.M.M. Rahman, A.K.M.F. Rahman, S. Rahman and S. Uga, 2017a. Quality aspect and heavy metal concentration of five important fishes of the Brahmaputra river in Mymensingh district of Bangladesh. Res. Soc. Diet. Habits., 37(2): 27-36.

Mansur, M.A., S. Rahman, M.N.A. Khan, M.S. Reza, Kamrunnahar, S. Uga, 2013. Study on the quality and safety aspect of three sun-dried fish Afr. J. Agric. Res., 8(41): 5149-5155.

Reza, M.S., M.A. Mansur and M. Kamal, 2020. Organoleptic, chemical, microbiological quality and heavy metal safety of traditionally dried marine fish of Bangladesh. Curr. Res. Agric. Food Sci., 3. DOI: $10.9734 / \mathrm{bpi} / \mathrm{crafs} / \mathrm{v} 3$ : 